\title{
Global financial markets: Factors influencing the global financial markets
}

\author{
Pshdar Abdalla Hamza ${ }^{1}$, Bawan Yassin Sabir ${ }^{2}$, Khowanas Saeed Qader ${ }^{3}$, Hassan \\ Mahmood Aziz ${ }^{4}$, Bayar Ali Ismeal ${ }^{5}$, Sarhang Sorguli ${ }^{6}$, Bayar Gardi ${ }^{7}$, Govand Anwar ${ }^{8}$
}

\author{
${ }^{1}$ Department of Business Administration, Kurdistan Technical Institute, Sulaymaniyah, Iraq. \\ ${ }^{2}$ Department of Accounting, College of Administration and Financial Sciences, Knowledge University, Kirkuk Road, 44001 Erbil, \\ Kurdistan Region, Iraq.
}

${ }^{3}$ Department of accounting and finance, College of Administrations and economics, Lebanese French university, Kurdistan region, Iraq ${ }^{4}$ Department of Accounting and Finance, Faculty of Economics and Administrative Sciences, Cyprus International University, Mersin 10, Haspolat 99040, Cyprus.

${ }^{5}$ Department of Accounting, Erbil Technical College, Erbil Polytechnic University.

${ }^{6}$ Department of Accounting, College of Administration and Financial Sciences, Knowledge University, Kirkuk Road, 44001 Erbil, Kurdistan Region, Iraq.

${ }^{7}$ Department of Accounting, College of Administration and Financial Sciences, Knowledge University, Kirkuk Road, 44001 Erbil, Kurdistan Region, Iraq. Email: bayar.gardi@knu.edu.iq , https://orcid.org/0000-0001-9724-7250

${ }^{8}$ Department of Business Administration, College of Administration and Financial Sciences, Knowledge University, Kirkuk Road, 44001 Erbil, Kurdistan Region, Iraq.

Received: 12 May 2021; Received in revised form: 11 Jun 2021; Accepted: 16 Jun 2021; Available online: 23 Jun 2021

\begin{abstract}
The worldwide recession began in earnest with a series of acute financial crises in key developed nations that occurred simultaneously with the freezing of financial markets around the world and the steep decline in global trade. The current research focused on assessing the impact of (Global economy, Business growth and development, and Inflation) ton global financial markets. The present thesis was analyzed using a questionnaire. Sample design is the technique or process that the researcher is able to accept in selecting objects for the survey is referred to as sample design. The research sample was chosen using a random sampling method and carried out in various businesses located in Kurdistan region of Iraq. A total of 280 questionnaires were issued, but only 228 participants completed them correctly. In order to examine the aspect of factors (Global economy, Business development and growth, and Inflation) to measure the influence on sustained competitive advantage in small and medium businesses in Kurdistan region of Iraq. Participants were asked to rate the value of each object on a five-point scale ranging from unimportant to highly important. The findings revealed that the implications of the first hypothesis: Global economy strongly predicts global financial markets (Beta is weight 0.801, p.001), implying that Global economy would have a clear beneficial relationship with global financial markets based on these findings, the implications of the second hypothesis: Business development and growth strongly predicts global financial markets (Beta is weight 0.719, p.001), implying that business development and growth would have a clear beneficial relationship with global financial markets based on these findings, and finally the implications of the third hypothesis: inflation strongly predicts global financial markets (Beta is weight 0.689, p.001), implying that Inflation would have a clear beneficial relationship with global financial markets based on these findings.
\end{abstract}

Keywords-Global Financial Markets, Inflation, Business Development and Growth, Global economy. 


\section{INTRODUCTION}

The current monetary system is full of perverse incentives that cause key personnel in virtually all important financial institutions including commercial and investment banks, hedge and private equity funds, insurance companies (Gulzar, et al. 2019), and mutual and pension funds to take unnecessary risk when the financial markets are doing well. The worldwide recession began in earnest with a series of acute financial crises in key developed nations that occurred simultaneously with the freezing of financial markets around the world and the steep decline in global trade. In the years that have followed, the global economy has witnessed dramatic examples of emerging market country capital flows' ( (Zhang, et al. 2020). So complicated that they are intrinsically opaque, modern financial goods have evolved to the point where such complicated goods have several deficiencies and are unfit for all but the wealthiest of investors. It is not possible to properly price, it is not offered on marketplaces, and it is not liquid. Riotously across numerous asset classes and financial markets, this phenomenon quickly proliferated (Elsayed, et al. 2020). There were numerous subprime mortgage delinquencies in the years leading up to the financial crisis due to rising interest rates and declining house prices (Long, et al. 2021). This created uncertainty regarding the value of various structured credit products which had these securities as a portion of their underlying portfolios. The end result was that hedge funds that held asset-backed securities and other structured products were forced to set aside additional capital, since market volatility caused increasing margin requirements (Popkova \& Parakhina, 2018). There was a brief period during which financial spillovers to other nations transformed into problems in the real sector, wherein economies whose economic growth is largely dependent on diminishing demand and available trade financing saw their domestic industrial production and GDP growth plummet (Gardi, 2021). A wide range of international issues is raised by SWFs (Tskhadadze \& Chernorizova, 2018), which are becoming increasingly important. While governments may be fearful of exposing their country to outside influences, such investments may be held back by the political and economic ramifications as well. It's apparent that the pandemic has had severe economic repercussions. Over the short term, many countries' economic operations are severely restricted by stringent quarantine rules being adopted by several countries. It's possible that long-term economic impacts from this pandemic will result through widespread unemployment and business failures. In other areas, such as tourism and aviation, it is obvious that difficulties are ahead. The financial markets of the world are interconnected. They play a crucial role in global integration (Sehgal, et al. 2019); in some senses, they are more centrally involved than actual trade in real goods (Ismael, et al. 2021). This ties up with the interconnectedness of the financial markets; occurrences in one market can have a direct impact on another in the space of seconds. The stance that global investors have toward a country's debt. With respect to monetary policy, it's the responsibility of the country's central bank to make all of the final decisions (Dias, et al. 2019). Also, it's more important for the countries near the financial centre to follow national guidelines rather than the region's (Gardi, 2021). The underdeveloped, but useful, qualities of naive inflation targeting monetary rules only come into play when the monetary policy responds to external disturbances while the market is still distorted. However, it does not entail that any self-oriented monetary policy is ineffectual (Sorguli, et al. 2021). Alternatively, if this reduction was determined solely by the favorable market conditions in global capital markets, swift and unexpected changes in these conditions such as an abrupt increase in international investors' risk aversion - could put the supposedly more creditworthy entity at significant risk (Saleh et al. 2021). Many studies have found that financial crises are almost often followed by currency exchange in other countries, and financial markets are typically more closely tied together at these times. But even though the crisis has appeared in varied forms, it has been able to touch the value systems of most countries around the world (Sorguli, et al. 2020). In the same time frame, because of the explosive growth of derivative financial markets and the increase in telecommunications and electronic trading, there was a considerable deregulation of financial markets. While it is possible for nations to hold strong influence in international bodies based solely on economic weight, it is more dependable for a nation to have an effective research and policy analysis system at the government, think tank, academic, and industrial levels. The use of the network method means that Asians should develop financial markets on a modular basis (Damit, et al. 2019), ensuring that the failure of one module would not prevent the system from functioning (Sabir, et al. 2021). The underlying issue of all financial crises is the breakdown of markets and governance. This global financial crisis is just another example of how things can go wrong (Hamza, et al. 2021). Famous example: For emerging markets, where government regulation often influences financial markets and often results in governmental ownership, the crisis could be traced to governance blunders by the corporation. The global financial crisis intensified, and this contributed to a situation in which more financial institutions in different parts of the world failed, along with worsening economic conditions worldwide (Hameed \& Anwar, 2018). That is why some governments moved to be more active in 
the market to help rescue their banks and other sectors of their economies. The number of research attempting to figure out the reasons of the subprime mortgage credit difficulties and the subsequent financial instability that precipitated the most recent global financial crisis is significant. However, as a result of the lack of an integrated global framework, there are many times when national regulatory regulations are challenged by market participants who seek to get around them through new financial developments. (Gardi, 2021)

\section{LITERATURE REVIEW}

\section{Global financial markets}

It has been noted that global financial markets are governed by the top economies because they are in possession of a great amount of resources that can be utilized for financing other country's projects and endeavors. These prominent countries realize the strength of their leverage by having these massive economic systems and they've used them to exert political influence on other countries on numerous occasions (Abdullah, et al. 2017).

\section{Global economy}

The global economy or the world economy is the economy of all humans throughout the world, and this is the global economic system, which includes all economic activities which are conducted both within and between nations, including production, consumption, economic management, work in general, exchange of financial values, and the exchange of goods and services. The growth of global capitalism notably in the post-war era, during which it expanded beyond international borders with little limitations imposed by national governments. There is now fierce debate regarding the global economy. Critics have said that, according to them, the economic theory of free markets (Abdullah \& Anwar, 2021), the advantages of free trade, and the proliferation of free trade zones have resulted in the loss of well-paid jobs in rich countries while producing sweatshops in poor countries. It is a common claim among supporters of the free movement of money that it helps promote investment in underdeveloped nations and create jobs in them. To maintain a balanced economy, every nation has to work together, and the nations are in a cooperative relationship. To put it simply, it is one gigantic entity. While globalization has contributed to the growth of commerce and industry, it has also created the trade and industry worldwide. This other way of saying that countries' economies are interwoven might be stated as follows (Ali, et al. 2021): "The way in which countries' economies have developed to operate as one system." When we look at the whole economy, it is all the economies of the world which we are considering together as one economic system. To sum it up, it is one enormous entity (Aziz, et al. 2021).
Another way to say it is that globalization has contributed to the emergence of a worldwide trading and industrial system. When it is put that way, it can be seen that countries' economies have developed to operate as one system. The global economy is the trade of goods and services that are linked into a single worldwide market. To simplify things, this may be defined as "It is almost a world where nations do not exist. Instead, the inhabitants and organizations in this geographic globe are there to perform research and development and perform sales (Hamza, et al. 2021).

Research Hypothesis (1): Global economy will have a significant influence on global financial markets.

\section{Business growth and development}

Business development is about the duties and processes of identifying, developing, and implementing growth prospects both within and across firms. Business, trade, and organizational theory are only one part of a larger range of topics of study called business studies. The improvement of an enterprise's success level is referred to as a process (Anwar \& Climis, 2017). The only way for businesses to increase revenue and/or grow is to increase the top line and/or the revenue of the business. This can be done by growing the revenue of the business by increasing sales or selling more products, or by increasing the bottom line and/or profitability of the operation by decreasing costs. No doubt about it: The most critical techniques to use in your company for both short- and long-term growth are to apply for new business (Anwar \& Qadir, 2017), as well as cultivate existing clients. This post is a part of a series that shows how having a firm grasp of different development and business growth techniques boosts corporate competitiveness. Corporation development, or creating value for an organization or business, can be described in its most basic form as an activity in which two or more parties are involved. This includes coming up with fresh ideas, suggestions for projects, and activities aimed at increasing profits. Rather than focusing on only the financial return, the purpose of business development is to help companies and customers in making informed business decisions that raise the value of their respective enterprises and customers. Business growth develops naturally in a constant cycle of adaptation and development as long as there are suitable conditions. This shows that companies can increase in some measurements, but not others. For instance, if profits from existing clients buying more causes revenue to expand (Anwar, 2017), it will do so even if the number of customers doesn't change. Not only can one metric go up while another goes down, but it is even conceivable for a measure to expand while another one declines; in this case, sales growth will result in a fall in product price, causing a business's overall revenue to decrease. All businesses, 
regardless of their scale-up strategy, need to rely on business growth financing. Finding the correct business growth capital for your firm involves skill and industry knowledge (Ali, et al. 2021). There is no such thing as a cookie-cutter approach, as each firm is different. You must make correct choices in order for growth to proceed. An illadvised choice will almost certainly lead to trouble. A better option is to create your structure from the ground up to minimise risk rather than fit your capital demand to an existing structure. business growth is mostly dependent on available resources, and generally necessitates a substantial up-front investment. Investing is always a good idea, whether it's acquiring a business or making an investment. In order to avoid excessive losses, one should be conservative when estimating future returns (CarlssonSzlezak, et al. 2020).

Research Hypothesis (2): Business growth and development will have a significant influence on global financial markets.

\section{Inflation}

In accounting, general level of prices rise in the general price level of an economy over a period of time. When the general price level rises, each unit of currency will purchase fewer products and services. Inflation is a long-term increase in the general price level of an economy over a period of time. When the general price level rises, each unit of currency can buy fewer products and services; as a result, inflation indicates a decrease in the purchasing power of each unit of money - a loss of real value in the medium of exchange and unit of account within the economy (Anwar $\&$ Climis, 2017). Contrary to inflation, which is a rise in the overall price level of goods and services, deflation is a continuous fall in the price level (Anwar \& Qadir, 2017). For the most part, the inflation rate is measured as an annualized percentage change in a general price index, such as the consumer price index, and is sometimes referred to as inflation. As unpleasant as it can be to think about the value of your cash losing purchasing power, economists see a modest amount of inflation as a sign of a healthy economy (Ahmed, et al. 2021). A moderate inflation rate encourages you to spend or invest your money today, rather with the benefits of having the money spent or invested and the associated joys and benefits of it. Inflation is an increase in the costs of all goods and services that most people purchase on a daily or regular basis, such as food, clothing, housing, recreation, transportation, and personal care products. Inflation tracks the average price change in a group of items, both those in stock and those that enter the market, through time (Abdullah, et al. 2017).

Research Hypothesis (3): Inflation will have a significant influence on global financial markets.

\section{METHOD}

In order to interpret the present analysis, a quantitative approach was used. The current research focused on assessing the impact of factors (Global economy, Business development and growth, and Inflation) to measure the influence on sustained competitive advantage in small and medium businesses in Kurdistan region of Iraq. The present thesis was analyzed using a questionnaire. Sample design is the technique or process that the researcher is able to accept in selecting objects for the survey is referred to as sample design. The research sample was chosen using a random sampling method and carried out in various locations in Kurdistan region of Iraq. A total of 280 questionnaires were issued, but only 228 participants completed them correctly. In order to examine the aspect of factors (Global economy, Business development and growth, and Inflation) to measure the influence on sustained competitive advantage in small and medium businesses in Kurdistan region of Iraq. Participants were asked to rate the value of each object on a five-point scale ranging from unimportant to highly important.

\section{Findings}

The current research focused on assessing the impact of factors (Global economy, Business development and growth, and Inflation) to measure the influence on sustained competitive advantage in small and medium businesses in Kurdistan region of Iraq. In order to measure factors as Inintangible resources for global financial markets, the researchers set three independent variables, theses variables are (Global economy, Business development and growth, and Inflation) on the other hand global financial markets. The researchers applied simple regression analysis to measure the influence of each independent variable separately on global financial markets as small and medium enterprises in Kurdistan region of Iraq.

Table.1: KMO and Bartlett Sphericity Test of Self-rating Items

\begin{tabular}{|l|l|l|l|l|l|l|}
\hline No & Factors & N of items & Sample & KMO & \multicolumn{2}{|l|}{ Bartlett test } \\
& & & & & Chi-Square & Sig \\
\hline 1 & Global economy & 12 & 228 & & & \\
\cline { 1 - 1 } & Business development and growth & 10 & 228 & & 5127.2 & .000 \\
\hline
\end{tabular}




\begin{tabular}{|l|l|l|l|l|l|l|}
\hline 3 & Inflation & 11 & 228 & .899 & & \\
\cline { 1 - 3 } & Global financial markets & 11 & 228 & & \\
\hline
\end{tabular}

As we can see in table (1), the outcome of KMO is .899 which is higher than .001 this indicates that the sample size used for the current study was more than adequate. Furthermore, the result of Chi-Square is 5127.2 with the significant level .000.

Table 2: Factor Analysis

\begin{tabular}{|c|c|c|c|c|c|c|}
\hline \multirow[t]{2}{*}{ No } & \multirow[t]{2}{*}{ Components } & \multirow[t]{2}{*}{$\begin{array}{l}\mathrm{N} \text { of } \\
\text { Items }\end{array}$} & \multirow[t]{2}{*}{$\mathbf{N}$} & \multirow[t]{2}{*}{ Eigenvalue } & \multicolumn{2}{|c|}{$\begin{array}{c}\text { Rotation Sums of Squared } \\
\text { Loadings }\end{array}$} \\
\hline & & & & & $\begin{array}{c}\% \text { of } \\
\text { Variance }\end{array}$ & Cumulative \\
\hline 1 & Global economy & 12 & 228 & 3.211 & 21.157 & 19.784 \\
\hline 2 & $\begin{array}{l}\text { Business development and } \\
\text { growth }\end{array}$ & 10 & 228 & 4.025 & 20.521 & 32.521 \\
\hline 3 & Inflation & 11 & 228 & 1.258 & 12.528 & 39.632 \\
\hline 4 & Global financial markets & 11 & 228 & 2.74 & 12.251 & 41.012 \\
\hline
\end{tabular}

Table (2) demonstrates three independent variables (Global economy, Business development and growth, and Inflation) and a dependent variable (Global financial markets). As for Global economy as first factor, which had twelve item explained $21.157 \%$ of the total variance. As for Business development and growth as second factor, which had ten items explained $20.521 \%$ of the total variance. As for Inflation as third factor, which had eleven items explained $12.528 \%$ of the total variance. And finally, as for Global financial markets as dependent variable, which had eleven items explained $12.251 \%$ of the total variance.

Table 3: Reliability analysis

\begin{tabular}{|c|c|c|}
\hline \multicolumn{2}{|c|}{ Reliability Statistics } \\
\hline Factor & Cronbach's Alpha & N of Items \\
\hline Global economy & .798 & 12 \\
\hline Business development and growth & .732 & 10 \\
\hline Inflation & .749 & 11 \\
\hline Global financial markets & .803 & 11 \\
\hline
\end{tabular}

As seen in table (3), the reliability analysis for 44 items used to measure the influence factors (Global economy, Business development and growth, and Inflation) to measure the influence on sustained competitive advantage in small and medium businesses in Kurdistan region of Iraq. The above 44 questions were distributed as follow; 12 items for Global economy, 10 items for Business development and growth, 11 items for Global economy, and 11 items for Global financial markets. The researchers applied reliability analysis to find out the reliability for each factors, the findings revealed as follow: as for Global economy was found the Alpha to be .798 for 12 questions which indicated that all 12 questions used to measure Global economy were reliable for the current study, as for Business development and growth was found the Alpha to be .732 for 10 questions which indicated that all 10 questions used to measure Business development and growth were reliable for the current study, as for Global economy was found the Alpha to be .749 for 11 questions which indicated that all 11 questions used to measure Global economy were reliable for the current study, and finally as for Global financial markets as dependent variable was found the Alpha to be .803 for 11 questions which indicated that all 11 questions used to measure Global financial markets as dependent variable were reliable for the current study. 
First Research Hypothesis

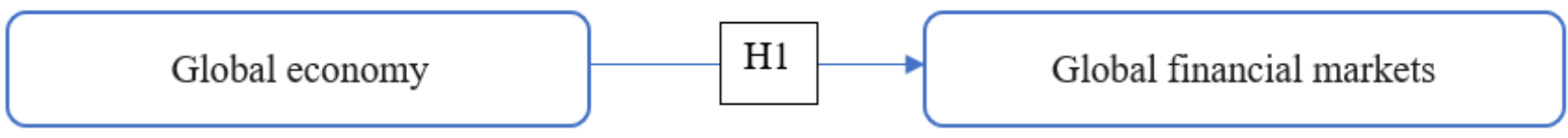

Table 4: Correlation analysis between Global economy and global financial markets

\begin{tabular}{|l|l|c|c|}
\hline \multicolumn{3}{|c|}{ Correlations } \\
\hline Variables & Pearson Correlation & Global financial markets & Global economy \\
\hline \multirow{3}{*}{$\begin{array}{l}\text { Global financial } \\
\text { markets }\end{array}$} & Pearson Correlation & 1 & $.776^{* *}$ \\
\cline { 2 - 4 } & Sig. (2-tailed) & & .000 \\
\cline { 2 - 4 } & $\mathrm{N}$ & 228 & 228 \\
\hline Global economy & Pearson Correlation & $.776^{* *}$ & 1 \\
\cline { 2 - 4 } & Sig. (2-tailed) & .000 & 228 \\
\cline { 2 - 4 } & $\mathrm{N}$ & 228 & \\
\hline$* *$ Correlation is significant at the 0.01 level (2-tailed). & \\
\hline
\end{tabular}

As it can be seen in table (4), the correlation analysis between global economy as a intangible resource to measure its influence on global financial markets in small and medium businesses in Kurdistan region of Iraq. The finding revealed that the value of Pearson correlation $\left(\mathrm{r}=.776^{* *}, \mathrm{p}<0.01\right)$, this indicated that there is positive and strong correlation between global economy and global financial markets.

Table 5-Model Summary of Global economy

\begin{tabular}{|l|c|c|r|r|}
\hline \multicolumn{5}{|c|}{ Model Summary } \\
\hline Model & $\mathrm{R}$ & R Square & Adjusted R Square & Std. Error of the Estimate \\
\hline 1 & $.768^{\mathrm{a}}$ & .721 & .711 & .20711 \\
\hline \multicolumn{2}{|l}{ a. Predictors: (Constant), Global economy } \\
\hline
\end{tabular}

Regression analysis is the study of interactions between variables. $\mathrm{Y}=\mathrm{f}(\mathrm{x} 1, \mathrm{x} 2, \ldots \mathrm{Xc})$ The aim of regression analysis is to determine how $\mathrm{Y}$ can affect and alter $\mathrm{X}$. The Global economy approach is treated as an independent variable in this section, while global financial markets is treated as a dependent variable. The volatility of a comparative advantage will be used to calculate its total difference. The variations are determined by calculating the sum of the squares of the expected competitive advantage values by the

Table 6-ANOVA of Global economy overall mean divided by the number of participants. After dividing the variance by the overall variance of comparative benefit, the researcher discovered the sum or percentage of total differences or variances that are compensated for using regression analysis. The number can range from 0 to 1 and is defined by $\mathrm{R}$ Square. The value of $\mathrm{R}$ square $=.721$ as seen in Table (5), indicating that 77 percent of total variation has been clarified.

\begin{tabular}{|l|l|r|r|r|r|c|}
\hline \multicolumn{7}{|l|}{ ANOVA } \\
\hline \multicolumn{2}{|l|}{ Model } & Sum of Squares & df & Mean Square & F & Sig. \\
\hline \multirow{3}{*}{1} & Regression & 144.682 & 1 & 143.239 & 223.228 & $.000^{\mathrm{b}}$ \\
\cline { 2 - 7 } & Residual & 44.3825 & 785 & .045 & & \\
\cline { 2 - 7 } & Total & 189.0645 & 786 & & & \\
\hline \multicolumn{2}{|l|}{ a. Dependent Variable: Global financial markets } \\
\hline
\end{tabular}

This article can be downloaded from here: www.ijaems.com 
b. Predictors: (Constant), Global economy

Table (6) shows that the F value for Global economy as an independent variable $=223.228$, indicating that there is a significant relationship between Global economy and global financial markets (223.228>1).

Table 7-Coefficients Analysis Global economy and global financial markets

\begin{tabular}{|c|c|c|c|c|c|c|}
\hline \multicolumn{7}{|c|}{ Coefficients } \\
\hline \multirow{2}{*}{\multicolumn{2}{|c|}{ Model }} & \multicolumn{2}{|c|}{$\begin{array}{c}\text { Unstandardized } \\
\text { Coefficients }\end{array}$} & $\begin{array}{l}\text { Standardized } \\
\text { Coefficients }\end{array}$ & $\mathrm{t}$ & Sig. \\
\hline & & B & Std. Error & Beta & & \\
\hline \multirow[t]{2}{*}{1} & (Constant) & .297 & .051 & & 3.521 & .000 \\
\hline & Global economy & .791 & .017 & .801 & 52.125 & .000 \\
\hline
\end{tabular}

Table (7) shows the implications of the first hypothesis: Global economy strongly predicts global financial markets (Beta is weight 0.801 , p.001), implying that Global economy would have a clear beneficial relationship with global financial markets based on these findings.

Second Research Hypothesis

Business development and growth

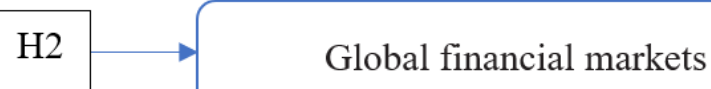

Table 8: Correlation analysis between Business development and growth and global financial markets

\begin{tabular}{|l|l|c|c|}
\hline \multicolumn{2}{|c|}{ Correlations } \\
\hline Variables & Pearson Correlation & Global financial markets & $\begin{array}{c}\text { Business development and } \\
\text { growth }\end{array}$ \\
\hline \multirow{2}{*}{$\begin{array}{l}\text { Global financial } \\
\text { markets }\end{array}$} & Pearson Correlation & 1 & $.698^{* *}$ \\
\cline { 2 - 4 } & Sig. (2-tailed) & $\mathrm{N}$ & .000 \\
\cline { 2 - 4 } & $\mathrm{N}$ & 228 \\
\hline \multirow{2}{*}{$\begin{array}{l}\text { Business } \\
\text { development } \\
\text { and growth }\end{array}$} & Pearson Correlation & $.698^{* *}$ & 1 \\
\cline { 2 - 4 } & Sig. (2-tailed) & .000 & 228 \\
\cline { 2 - 4 } & $\mathrm{N}$ & 228 & \\
\hline
\end{tabular}

As it can be seen in table (8), the correlation analysis between business development and growth as a intangible resource to measure its influence on global financial markets in small and medium businesses in Kurdistan region of Iraq. The finding revealed that the value of Pearson correlation $\left(r=.698^{* *}, \mathrm{p}<0.01\right)$, this indicated that there is positive and strong correlation between business development and growth and global financial markets. 
Table 9-Model Summary of Business development and growth

\begin{tabular}{|l|r|r|r|r|}
\hline \multicolumn{5}{|c|}{ Model Summary } \\
\hline Model & $\mathrm{R}$ & R Square & Adjusted R Square & Std. Error of the Estimate \\
\hline 1 & .671 & .632 & .618 & .18625 \\
\hline \multicolumn{7}{|l|}{ a. Predictors: (Constant), Business development and growth } \\
\hline
\end{tabular}

Regression analysis is the study of interactions between variables. $\mathrm{Y}=\mathrm{f}(\mathrm{x} 1, \mathrm{x} 2, \ldots \mathrm{Xc})$ The aim of regression analysis is to determine how $\mathrm{Y}$ can affect and alter $\mathrm{X}$. The business development and growth approach is treated as an independent variable in this section, while global financial markets is treated as a dependent variable. The volatility of a comparative advantage will be used to calculate its total difference. The variations are determined by calculating the sum of the squares of the expected competitive advantage

Table 9-ANOVA of Business development and growth

\begin{tabular}{|l|l|r|r|r|r|c|}
\hline \multicolumn{7}{|l|}{ ANOVA } \\
\hline \multirow{2}{*}{1} & Sum of Squares & df & Mean Square & F & Sig. \\
\cline { 2 - 7 } & Regression & 131.078 & 1 & 129.649 & 293.198 & $.000^{\text {b }}$ \\
\cline { 2 - 7 } & Residual & 38.219 & 469 & .038 & & \\
\cline { 2 - 7 } & Total & 169.297 & 470 & & \\
\hline \multicolumn{7}{|l|}{ a. Dependent Variable: Global financial markets } \\
\hline \multicolumn{2}{|l}{ b. Predictors: (Constant), Business development and growth } \\
\hline
\end{tabular}

Table (10) shows that the F value for business development and growth as an independent variable $=293.198$, indicating that there is a significant relationship between business development and growth and global financial markets $(293.198>1)$.

Table 11-Coefficients Analysis Business development and growth and global financial markets

\begin{tabular}{|c|c|c|c|c|c|c|}
\hline \multicolumn{7}{|c|}{ Coefficients } \\
\hline \multirow{2}{*}{\multicolumn{2}{|c|}{ Model }} & \multicolumn{2}{|c|}{$\begin{array}{c}\text { Unstandardized } \\
\text { Coefficients }\end{array}$} & \multirow{2}{*}{$\begin{array}{c}\begin{array}{c}\text { Standardized } \\
\text { Coefficients }\end{array} \\
\text { Beta }\end{array}$} & \multirow[t]{2}{*}{$\mathrm{t}$} & \multirow[t]{2}{*}{ Sig. } \\
\hline & & B & Std. Error & & & \\
\hline \multirow[t]{2}{*}{1} & (Constant) & .331 & .049 & & 5.129 & .000 \\
\hline & Business development and growth & .703 & .028 & .719 & 51.638 & .000 \\
\hline
\end{tabular}

Table (11) shows the implications of the second hypothesis: Business development and growth strongly predicts global financial markets (Beta is weight 0.719, p.001), implying that business development and growth would have a clear beneficial relationship with global financial markets based on these findings.

Third Research Hypothesis

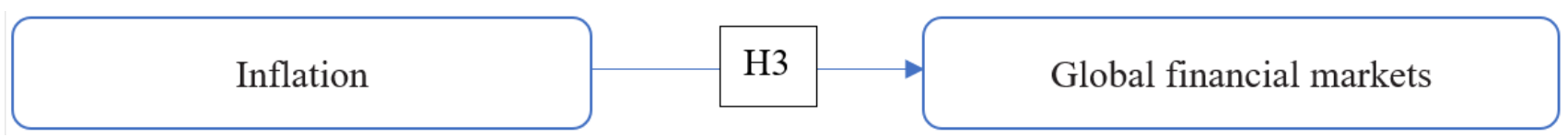


Table 12: Correlation analysis between Inflation and global financial markets

\begin{tabular}{|l|l|c|c|}
\hline \multicolumn{3}{|c|}{ Correlations } \\
\hline Variables & Pearson Correlation & Global financial markets & Inflation \\
\hline \multirow{2}{*}{$\begin{array}{l}\text { Global financial } \\
\text { markets }\end{array}$} & Pearson Correlation & 1 & $.747^{* *}$ \\
\cline { 2 - 4 } & Sig. (2-tailed) & & .000 \\
\cline { 2 - 4 } & $\mathrm{N}$ & 228 & 228 \\
\hline \multirow{3}{*}{ Inflation } & Pearson Correlation & $.747^{* *}$ & 1 \\
\cline { 2 - 4 } & Sig. (2-tailed) & .000 & 228 \\
\cline { 2 - 4 } & $\mathrm{N}$ & 228 & \\
\hline$* *$ Correlation is significant at the 0.01 level (2-tailed). & \\
\hline
\end{tabular}

As it can be seen in table (12), the correlation analysis between inflation as a intangible resource to measure its influence on global financial markets in small and medium businesses in Kurdistan region of Iraq. The finding revealed that the value of Pearson correlation $\left(r=.747^{* *}, p<0.01\right)$, this indicated that there is positive and strong correlation between inflation and global financial markets.

Table 13-Model Summary of Business development and growth

\begin{tabular}{|l|c|c|r|r|}
\hline \multicolumn{5}{|c|}{ Model Summary } \\
\hline Model & $\mathrm{R}$ & R Square & Adjusted R Square & Std. Error of the Estimate \\
\hline 1 & .751 & .698 & .618 & .20154 \\
\hline \multicolumn{2}{|l|}{ a. Predictors: (Constant), Inflation } \\
\hline
\end{tabular}

Regression analysis is the study of interactions between variables. $\mathrm{Y}=\mathrm{f}(\mathrm{x} 1, \mathrm{x} 2, \ldots \mathrm{Xc})$ The aim of regression analysis is to determine how $\mathrm{Y}$ can affect and alter $\mathrm{X}$. The inflation approach is treated as an independent variable in this section, while global financial markets is treated as a dependent variable. The volatility of a comparative advantage will be used to calculate its total difference. The variations are determined by calculating the sum of the squares of the expected competitive advantage values by the overall mean divided by the number of participants. After dividing the variance by the overall variance of comparative benefit, the researcher discovered the sum or percentage of total differences or variances that are compensated for using regression analysis. The number can range from 0 to 1 and is defined by $\mathrm{R}$ Square. The value of $\mathrm{R}$ square $=.698$ as seen in Table (13), indicating that 69 percent of total variation has been clarified.

Table 14-ANOVA of Inflation

\begin{tabular}{|l|l|r|r|r|r|r|}
\hline \multicolumn{7}{|l|}{ ANOVA } \\
\hline \multicolumn{2}{|l|}{ Model } & Sum of Squares & df & Mean Square & F & Sig. \\
\hline 1 & Regression & 118.211 & 1 & 112.001 & 118.206 & $.000^{\mathrm{b}}$ \\
\cline { 2 - 7 } & Residual & 21.682 & 722 & .033 & & \\
\cline { 2 - 7 } & Total & 139.893 & 723 & & \\
\hline \multicolumn{2}{|l|}{ a. Dependent Variable: Global financial markets } \\
\hline \multicolumn{2}{|l|}{ b. Predictors: (Constant), Inflation } \\
\hline
\end{tabular}

Table (14) shows that the $\mathrm{F}$ value for inflation as an independent variable $=118.206$, indicating that there is a significant relationship between inflation and global financial markets (118.206>1). 
Table 15-Coefficients Analysis Inflation and global financial markets

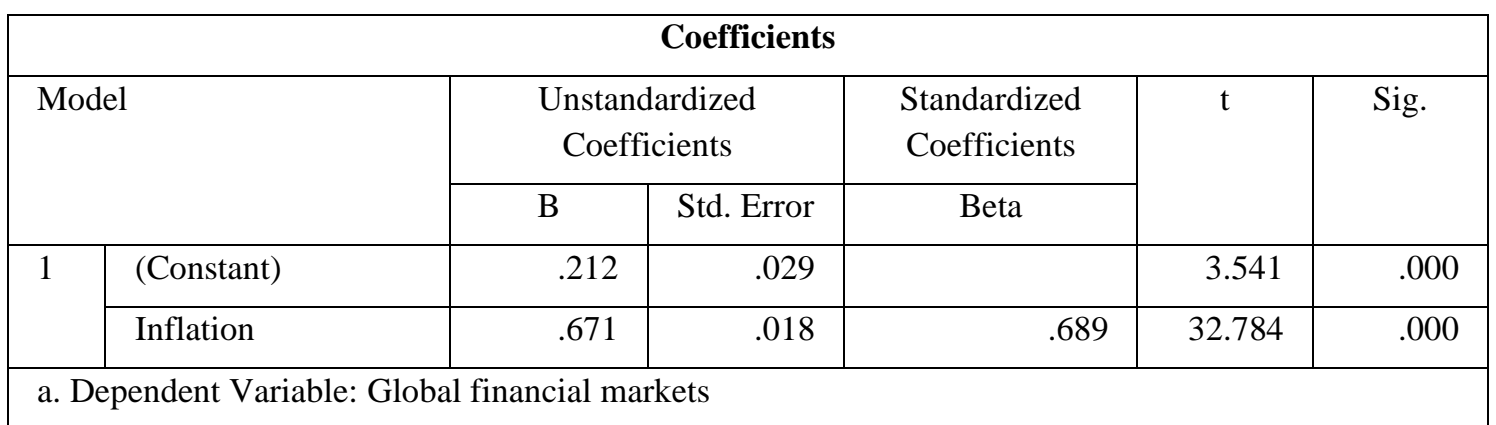

Table (15) shows the implications of the third hypothesis: inflation strongly predicts global financial markets (Beta is weight 0.689, p.001), implying that Inflation would have a clear beneficial relationship with global financial markets based on these findings.

\section{CONCLUSION}

The world economy, also known as the world economic activity, is the economy of all humans worldwide, and it is the global economic system, which includes all economic activities conducted both within and between nations, such as production, consumption, economic management, work in general, the exchange of financial values, and the exchange of goods and services. The expansion of global capitalism, particularly in the postwar period, when it spread across international borders with little constraints imposed by national governments. The global economy is currently the subject of heated debate. According to critics, free market economic theory, the benefits of free trade, and the spread of free trade zones have resulted in the loss of well-paid jobs in rich countries while producing sweatshops in impoverished countries. It is a popular assertion made by proponents of free money movement that it encourages investment and job creation in developing countries. Every nation must collaborate to maintain a balanced economy, and the nations are in a cooperative relationship. To put it simply, it is a massive entity. While globalization has aided the growth of commerce and industry, it has also produced new trade and industry on a global scale. Another way to explain that countries' economies are intertwined is: "the method in which countries' economies have developed to work as one system." When we look at the global economy, we are seeing all of the world's economies as a single economic system. To summarize, it is a massive entity. Another way to put it is that globalization has aided in the development of a global commerce and industrial system. When presented this way, it is clear that countries' economies have evolved to function as a single system. The global economy is the exchange of commodities and services on a single global market. To put it simply, "it is nearly a world where states do not exist." Instead, the residents and enterprises in this geographical world are there to conduct research and development as well as sales.
It has been observed that the top economies rule global financial markets since they have a large quantity of resources that can be used to fund other countries' projects and undertakings. These powerful countries recognize the power of their huge economic systems and have utilized them to exert political influence on other countries on multiple occasions. Business development entails the tasks and processes of discovering, developing, and executing growth opportunities both within and across organizations. Business, commerce, and organizational theory are simply a subset of the greater field of study known as business studies. A process is the improvement of an enterprise's success level. The only way for a business to increase revenue and/or grow is to improve its top line and/or revenue. This can be accomplished by increasing the business's revenue by increasing sales or selling more products, or by boosting the operation's bottom line and/or profitability by cutting costs. There is no doubt about it: Applying for new business and cultivating existing clients are the two most important tactics to use in your company for both short- and long-term success. This post is part of a series that demonstrates how understanding various development and business growth approaches improves corporate competitiveness. In its most basic form, corporation development, or creating value for an organization or business, can be defined as an activity involving two or more partners. This includes coming up with new ideas, project suggestions, and profit-boosting activities. Instead of focusing solely on financial returns, the goal of business development is to assist organizations and consumers in making informed business decisions that increase the value of their respective enterprises and customers. As long as the conditions are favorable, business growth occurs naturally in a continuous cycle of adaptation and development. This demonstrates that businesses can improve in certain areas but not others. For example, if profits from existing customers purchasing more cause 
revenue to grow, revenue will grow even if the number of consumers does not change. Not only can one metric rise while another falls, but it is also possible for one metric to rise while another falls; in this scenario, sales increase will result in a drop in product price, causing a company's overall revenue to fall. Regardless of their scale-up approach, all businesses require business expansion financing. Finding the right business expansion finance for your company necessitates talent and industry knowledge. There is no such thing as a cookie-cutter strategy because each company is unique. In order for progress to occur, you must make the right decisions. An ill-advised decision will almost likely result in trouble. To reduce risk, it is preferable to design your structure from the bottom up rather than adapting your capital demand to an existing structure. Business growth is mostly determined by available resources and, in most cases, needs a significant initial investment. Whether it's acquiring a business or making an investment, investing is always a good decision. To minimize excessive losses, future returns should be estimated conservatively. In accounting, the general level of prices rises in an economy's general price level over time. When the general price level rises, each unit of money buys less goods and services. Inflation is a long-term increase in an economy's overall price level over time. When the general price level rises, each unit of currency can buy fewer goods and services; hence, inflation signifies a drop in the purchasing power of each unit of money - a loss of real value in the economy's medium of exchange and unit of account. In contrast to inflation, which is defined as an increase in the overall price level of goods and services, deflation is defined as a continuous decrease in the price level. The inflation rate is typically assessed as an annualized percentage change in a general price index, such as the consumer price index, and is sometimes referred to as inflation. As uncomfortable as it is to consider your money's purchasing power eroding, economists perceive a small amount of inflation as a sign of a healthy economy. A modest inflation rate encourages you to spend or invest your money now, rather than later, because of the rewards of having the money spent or invested, as well as the accompanying joys and benefits. Inflation is defined as an increase in the prices of all goods and services that the majority of people buy on a daily or regular basis, such as food, clothing, housing, recreation, transportation, and personal care products. Inflation measures the average price change over time of a collection of items, both those in stock and those that enter the market. The findings revealed that the implications of the first hypothesis: Global economy strongly predicts global financial markets (Beta is weight 0.801, p.001), implying that Global economy would have a clear beneficial relationship with global financial markets based on these findings, the implications of the second hypothesis: Business development and growth strongly predicts global financial markets (Beta is weight 0.719, p.001), implying that business development and growth would have a clear beneficial relationship with global financial markets based on these findings, and finally the implications of the third hypothesis: inflation strongly predicts global financial markets (Beta is weight 0.689, p.001), implying that Inflation would have a clear beneficial relationship with global financial markets based on these findings.

\section{REFERENCES}

[1] Gardi, B. (2021). Investigating the effects of Financial Accounting Reports on Managerial Decision Making in Small and Medium-sized Enterprises. Turkish Journal of Computer and Mathematics Education (TURCOMAT), 12(10), 2134-2142.

[2] Ismael, N. B., Sorguli, S., Aziz, H. M., Sabir, B. Y., Hamza, P. A., Gardi, B., \& Al-Kake, F. R. A. (2021). The Impact of COVID-19 on Small and Medium-Sized Enterprises in Iraq. Annals of the Romanian Society for Cell Biology, 24962505.

[3] Gardi, B. (2021). THE EFFECTS OF COMPUTERIZED ACCOUNTING SYSTEM ON AUDITING PROCESS: A CASE STUDY FROM NORTHERN IRAQ. Available at SSRN 3838327.

[4] Sorguli, S. H., \& Al-Kake, F. R. A. (2020). The impact of Accounting Information System on Internal Controls in Iraq. Solid State Technology, 63(5), 7024-7036.

[5] Damit, D. H. D. A., Harun, A., Martin, D., Othman, B., \& Ahmad, H. (2019). What makes a non-Muslim purchase halal food in a Muslim country? An application of theory of planned behaviour. Management Science Letters, 9(12), 2029-2038.

[6] Gulzar, S., Mujtaba Kayani, G., Xiaofen, H., Ayub, U., \& Rafique, A. (2019). Financial cointegration and spillover effect of global financial crisis: A study of emerging Asian financial markets. Economic research-Ekonomska istraživanja, 32(1), 187-218.

[7] Zhang, D., Hu, M., \& Ji, Q. (2020). Financial markets under the global pandemic of COVID-19. Finance Research Letters, 36, 101528.

[8] Elsayed, A. H., Nasreen, S., \& Tiwari, A. K. (2020). Timevarying co-movements between energy market and global financial markets: Implication for portfolio diversification and hedging strategies. Energy Economics, 90, 104847.

[9] Long, W., Guo, Y., \& Wang, Y. (2021). Information spillover features in global financial markets: A systematic analysis. Research in International Business and Finance, 57, 101395.

[10] Белозеров, С., Соколовская, Е., \& Сик, К. Ю. (2020). Fintech as a Precondition of Transformations in Global Financial Markets. Фopcaŭm, 14(2).

[11] Popkova, E. G., \& Parakhina, V. N. (2018, April). Managing the global financial system on the basis of artificial 
intelligence: possibilities and limitations. In International Conference Project "The future of the Global Financial System: Downfall of Harmony" (pp. 939-946). Springer, Cham.

[12] Fukuda, S. I., \& Tanaka, M. (2017). The impacts of emerging asia on global financial markets. Emerging Markets Finance and Trade, 53(12), 2725-2743.

[13] Tskhadadze, N. V., \& Chernorizova, N. V. (2018, April). International Financial Markets in the Conditions of Transformation of Financial System. In International Conference Project "The future of the Global Financial System: Downfall of Harmony” (pp. 757-764). Springer, Cham.

[14] Lahmiri, S., Uddin, G. S., \& Bekiros, S. (2017). Nonlinear dynamics of equity, currency and commodity markets in the aftermath of the global financial crisis. Chaos, solitons \& fractals, 103, 342-346.

[15] Adekoya, O. B., \& Oliyide, J. A. (2021). How COVID-19 drives connectedness among commodity and financial markets: Evidence from TVP-VAR and causality-inquantiles techniques. Resources Policy, 70, 101898.

[16] Sehgal, S., Saini, S., \& Deisting, F. (2019). Examining Dynamic Interdependencies Among Major Global Financial Markets. Multinational Finance Journal, 23(1-2), 103-139.

[17] Albulescu, C. T., Demirer, R., Raheem, I. D., \& Tiwari, A. K. (2019). Does the US economic policy uncertainty connect financial markets? Evidence from oil and commodity currencies. Energy Economics, 83, 375-388.

[18] Ali, M., Alam, N., \& Rizvi, S. A. R. (2020). Coronavirus (COVID-19)-An epidemic or pandemic for financial markets. Journal of Behavioral and Experimental Finance, 27, 100341.

[19] Dias, R., da Silva, J. V., \& Dionísio, A. (2019). Financial markets of the LAC region: Does the crisis influence the financial integration?. International Review of Financial Analysis, 63, 160-173.

[20] Lavinas, L. (2020). The Collateralization of Social Policy by Financial Markets in the Global South 1. In The Routledge international handbook of financialization (pp. 312-323). Routledge.

[21] Carlsson-Szlezak, P., Reeves, M., \& Swartz, P. (2020). What coronavirus could mean for the global economy. Harvard Business Review, 3, 1-10.

[22] Bello, J., \& Rodgers, T. (2019). Financial Contagion Effect and Investor Behavior in African Financial Markets During the 2007-09 Global Financial Crisis. Available at SSRN 3442636

[23] Wang, W., \& Enilov, M. (2020). The global impact of COVID-19 on financial markets. Available at SSRN 3588021.

[24] Xie, N., Hu, H., Fang, D., Shi, X., Luo, S., \& Burns, K. (2021). An empirical analysis of financial markets and instruments influencing the low-carbon electricity production transition. Journal of Cleaner Production, 280, 124415.

[25] Samadi, A. H., Owjimehr, S., \& Halafi, Z. N. (2021). The cross-impact between financial markets, Covid-19 pandemic, and economic sanctions: The case of Iran. Journal of policy modeling, 43(1), 34-55.

[26] Qarni, M. O., Gulzar, S., Fatima, S. T., Khan, M. J., \& Shafi, K. (2019). Inter-markets volatility spillover in US Bitcoin and financial markets. Journal of Business Economics and Management, 20(4), 694-714.

[27] Ali, B. J., \& Anwar, G. (2021). Factors Influencing the Citizens' Acceptance of Electronic Government. International Journal of Engineering, Business and Management, 5(1), 48-60. https://doi.org/10.22161/ijebm.5.1.5

[28] Saleh, P. F., Ali, B. J., Akoi, S., Najmalddin, B., Ali, R. S., $\&$ Anwar, G. (2021). Factors affecting the Success of Female Entrepreneurs in Kurdistan. International journal of Engineering, Business and Management (IJEBM), 5.

[29] Ali, B. J., Saleh, P. F., Akoi, S., Abdulrahman, A. A., Muhamed, A. S., Noori, H. N., \& Anwar, G. (2021, May). Impact of Service Quality on the Customer Satisfaction: Case study at Online Meeting Platforms. In Ali, BJ, Saleh, Akoi, S., Abdulrahman, AA, Muhamed, AS, Noori, HN, Anwar, G.(2021). Impact of Service Quality on the Customer Satisfaction: Case study at Online Meeting Platforms. International journal of Engineering, Business and Management (Vol. 5, No. 2, pp. 65-77).

[30] Abdullah, N. N., \& Anwar, G. (2021). An Empirical Analysis of Natural Gas as an Alternative Fuel for Internal Transportation. International Journal of English Literature and Social Sciences, 6(1).

[31] Anwar, K. (2017). Leading Construction Project Teams: The Effectiveness of Transformational Leadership in Dynamic Work Environments in Kurdistan. International Journal of Advanced Engineering, Management and Science, 3(10), 239925.

[32] Anwar, K., \& Qadir, G. H. (2017). A Study of the Relationship between Work Engagement and Job Satisfaction in Private Companies in Kurdistan. International Journal of Advanced Engineering, Management and Science, 3(12), 239944.

[33] Anwar, K., \& Climis, R. (2017). Analyzing the relationship between types of advertisement and customer choice: a study of retailer stores in erbil. The International Journal of Accounting and Business Society, 25(2), 43-52.

[34] Ali, B. J., Saleh, Akoi, S., Abdulrahman, A. A., Muhamed, A. S., Noori, H. N., Anwar, G. (2021). Impact of Service Quality on the Customer Satisfaction: Case study at Online Meeting Platforms. International journal of Engineering, Business and Management, 5(2), 65-77. https://dx.doi.org/10.22161/ijebm.5.2.6

[35] Hameed, A. A., \& Anwar, K. (2018). Analyzing the Relationship between Intellectual Capital and Organizational Performance: A Study of Selected Private Banks in Kurdistan. International Journal of Social Sciences \& Educational Studies, 4(4), 39.

[36] Sabir, B. Y., Othman, B .J., Gardi, B., Ismael, N. B., Hamza, P. A., Sorguli, S., Aziz, H. M., Ahmed, S. A., Ali, B. J., Anwar, G. (2021). Administrative Decentralization: The Transfer of Competency from The Ministry of Education to General Directorates. International Journal of Rural

112 
Development, Environment and Health Research, 5(3), 113. https://doi.org/10.22161/ijreh.5.3.1

[37] Abdullah, M. S., Toycan, M., \& Anwar, K. (2017). The cost readiness of implementing e-learning. CUSTOS E AGRONEGOCIO ON LINE, 13(2), 156-175.

[38] Ali, B. J., Anwar, G., Gardi, B., Othman, B. J., Aziz, H. M., Ahmed, S. A., Hamza, P. A., Ismael, N. B., Sorguli, S., Sabir, B. Y. (2021). Business Communication Strategies: Analysis of Internal Communication Processes. Journal of Humanities and Education Development, 3(3), 16-38. https://doi.org/10.22161/jhed.3.3.4

[39] Aziz, H. M., Othman, B. J., Gardi, B., Ahmed, S. A., Sabir, B. Y., Ismael, N. B., Hamza, P. A., Sorguli, S., Ali, B. J., Anwar, G. (2021). Employee Commitment: The Relationship between Employee Commitment And Job Satisfaction. Journal of Humanities and Education Development, 3(3), 54-66. https://doi.org/10.22161/jhed.3.3.6

[40] Sorguli, S., Gardi, B., Othman, B.J., Aziz, H. M., Ahmed, S. A., Sabir, B. Y., Ismael, N. B., Hamza, P. A., Ali, B. J., Anwar, G. (2021) Innovation: Knowledge Management in the Innovating Industries, 6(3), 10-23. https://dx.doi.org/10.22161/eec.63.2

[41] Hamza, P. A., Othman, B. J., Gardi, B., Sorguli, S., Aziz, H. M., Ahmed, S. A., Sabir, B. Y., Ismael, N. B., Ali, B. J., Anwar, G. (2021). Recruitment and Selection: The Relationship between Recruitment and Selection with Organizational Performance. International Journal of Engineering, Business and Management, 5(3), 1-13. https://doi.org/10.22161/ijebm.5.3.1

[42] Ahmed, S. A., Othman, B. J., Gardi, B., Sabir, B. Y., Ismael, N. B., Hamza, P. A., Sorguli, S., Aziz, H. M., Ali, B. J., Anwar, G. (2021). Students' Attitudes towards Learning English in the Kurdistan region of Iraq. International Journal of English Literature and Social Sciences, 6(3), 072-087. https://doi.org/10.22161/ijels.63.11

[43] Ismael, N. B., Othman, B. J., Gardi, B., Hamza, P. A., Sorguli, S., Aziz, H. M., Ahmed, S. A., Sabir, B. Y., Ali, B. J., Anwar, G. (2021). The Role of Training and Development on Organizational effectiveness. International Journal of Engineering, Business and Management, 5(3), 15-24. https://doi.org/10.22161/ijebm.5.3.3 